\title{
Selected applications of calixarene derivatives
}

\author{
Malgorzata Deska, Barbara Dondela, and Wanda Sliwa* \\ Jan Dlugosz University, Institute of Chemistry, Environmental Protection and Biotechnology, \\ 42-200 Czestochowa, Armii Krajowej 13/15 Street, Poland \\ E-mail:w.sliwa@ajd.czest.pl
}

DOI: http://dx.doi.org/10.3998/ark.5550190.p008.958

\begin{abstract}
The review consists of two parts. In the first part applications of calixarenes as sensors are described, paying attention to sensors of metal ions. The second part is concerned with other special applications of calixarenes.
\end{abstract}

Keywords: Complexation, extraction, monitoring, sensors, separation

\section{Table of Contents}

1. Introduction

2. Applications of Calixarenes as Extractants and Sensors

2.1. Extraction of actinides and lanthanides

2.2. Extraction of uranium

2.3. Sensing of $\mathrm{Pb}^{2+}$ and $\mathrm{Sr}^{2+}$ ions

2.4. Sensing of $\mathrm{Li}^{+}$ions

2.5. Sensing of $\mathrm{Al}^{3+}$ ions

2.6. Sensing of $\mathrm{Ni}^{2+}$ and $\mathrm{Hg}^{2+}$ ions

2.7. Sensing of $\mathrm{Cr}_{2} \mathrm{O}_{7}{ }^{2-}$ and $\mathrm{HCr}_{2} \mathrm{O}_{7}^{-}$ions

2.8. Sensing of $o$ - and $p$-nitrophenols

3. Other Applications of Calixarenes

3.1. Bodipy-based photosensitizer with PEGylated calixarene as a carrier

3.2. Recovery of butanol from dilute aqueous solutions with the use of immobilized calixarenes

3.3. Calixarene-coated solid-phase microextraction fibres

3.4. Calixarene-supported lanthanide single-molecule magnet

4. Conclusions

References 


\section{Introduction}

Calixarenes are interesting cage macrocycles, widely investigated due to their valuable properties, especially formation of inclusion complexes; ${ }^{1}$ these macrocycles are promising for a variety of applications. ${ }^{2}$ One should point out the use of calixarenes in the biological field ${ }^{3,4}$ and in design of pharmaceutic agents. ${ }^{5-7}$ Calixarenes form metal nanoparticles, ${ }^{8-10}$ e.g. AuNPs ${ }^{8,9}$ and AgNPs, ${ }^{10}$ as well as organic NPs, ${ }^{11}$ and serve for construction of sensors; ${ }^{12-14}$ they also may be used as extractants of f-elements. ${ }^{15,16}$

The present paper is a continuation of our previous reviews concerning covalently and noncovalently bound calixarene assemblies, ${ }^{17}$ calixarenes functionalized at wide and narrow rims, ${ }^{18}$ calixarenes substituted at meso positions, ${ }^{19}$ calixarene complexes with metal ions, ${ }^{20}$ as well as calixarenes and resorcinarenes. ${ }^{21}$

Besides classical calixarenes, also calixarenes containing modified meso bridges are known, ${ }^{22}$ they are calixradialenes, ${ }^{23}$ ketocalixarenes ${ }^{24}$ and homocalixarenes. ${ }^{25,26}$ The noncovalent calixarene assemblies with porphyrins ${ }^{27-29}$ are recently the theme of a large amount of reports. ${ }^{30}$

\section{Applications of calixarenes as extractants and sensors}

\subsection{Extraction of actinides and lanthanides}

The partitioning of the radionuclides ${ }^{137} \mathrm{Cs}$ and ${ }^{90} \mathrm{Sr}$, as well as actinides and lanthanides $\mathrm{An}(\mathrm{III}) / \mathrm{Ln}$ (III) from strongly acidic, high level activity nuclear waste (HLW) presents today a crucial challenge. Calix[4]arene functionalized by (carbamoylmethyl)diphenyl phosphine oxide (CMPO) group at the narrow ${ }^{31}$ or wide rim $^{32}$ was found to be efficient for An(III)/Ln(III) extraction. However the treatment of strongly acidic HLW by calixarenes is often accompanied by the unwanted co-transport of nitrate ions into the organic phase.

It is known that the hydrophobic cobalt bis(dicarbollide)ion $\mathbf{1}^{-}$behaves as an inorganic superacid, and is chemically and thermally stable. ${ }^{33}$ When $\mathbf{1}^{-}$is used in synergistic mixtures with various organic ionophores, it can form tight ion pairs with target radionuclides and intermolecularly compensate their positive charge. ${ }^{34}$ This behavior decreases or eliminates the nitrate co-transport into the organic phase. One should note that the anion $\mathbf{A}^{-}$related to $\mathbf{1}^{-}$is often introduced by use of $\mathbf{2}$, i.e. the dioxane derivative of $\mathbf{1}^{-}$by the cleavage of the dioxane ring.

It has been reported that calix[4]arene substituted at the narrow rim by two $\mathrm{A}^{-}$anions and two CMPO groups, i.e. calixarene of the $\mathrm{A}^{-}: \mathrm{B}$ ratio $2: 2$ shows a high efficiency of $\mathrm{An}(\mathrm{III}) / \mathrm{Ln}$ (III) extraction even from strongly acidic solutions. ${ }^{35}$ In continuation of this work, besides $\mathrm{A}^{-}$: $\mathrm{B}$ ratio influencing the extraction efficiency, the mutual (adjacent or distal) arrangement of $\mathrm{A}$ and $\mathrm{B}$ substituents has also been studied.

Calixarenes $\mathbf{3}^{-}, \mathbf{4}^{3-}, \mathbf{5}^{2-}$ substituted at the narrow rim by cobalt bis(dicarbollide) $\left(\mathrm{A}^{-}\right)$anions and by CMPO (B) groups, and calixarene $6^{2-}$ substituted at the wide rim by $\mathrm{A}^{-}$and $\mathrm{B}$, have been 
synthesized and investigated in view of their $\mathrm{An}(\mathrm{III}) / \mathrm{Ln}(\mathrm{III})$ extraction efficiency. ${ }^{36}$ (Calixarenes substituted by $\mathrm{A}^{-}$anions and $\mathrm{B}$ groups are further referred to as substituted calixarenes).

The narrow-rim substituted calixarenes can be divided into species of the $\mathrm{A}^{-}: \mathrm{B}$ ratio $1: 3$ (in $\mathbf{3}^{-}$), of the $A^{-}: B$ ratio $3: 1$, (in $\mathbf{4}^{3-}$ ) and of the $A^{-}: B$ ratio $2: 2$ (in $\mathbf{5}^{2-}$ ). The wide rim substituted calixarene $6^{2-}$ has the $\mathrm{A}^{-}: \mathrm{B}$ ratio $2: 2$.

2.1.1. Synthesis of narrow rim substituted calix[4]arenes $3^{-}, 4^{3-}, 5^{2-}$ and of the wide rim substituted calixarene $6^{2-}$.

- Synthesis of calixarenes $3^{-}, 4^{3-}, 5^{2-}$. The synthesis of $\mathbf{3}^{-}$begins with the deprotonation of hydroxyl groups of the starting calixarene $\mathbf{3}$ by $\mathrm{NaH}$ followed by treatment with $\mathbf{2}$ in toluene/ DME mixture (2:1) (DME = 1,2-dimethoxyethane); the ring cleavage of 2 affords calixarene $\mathbf{3 a}{ }^{-}$. The subsequent reduction of $\mathbf{3 a}^{-}$with $\mathrm{BH}_{3} \cdot \mathrm{SMe}_{2}$ yields $\mathbf{3 b}$ which upon deprotonation with $\mathrm{NaH}$ reacts with nitrophenyl ester of phosphoryl acetic acid (E) to give $\mathbf{3}^{-}$. Similar procedure carried out on calixarene $\mathbf{4}$ afforded via $\mathbf{4 a}^{\mathbf{3 -}}$ and $\mathbf{4 b}^{\mathbf{2}}$ the desired calixarene $\mathbf{4}^{3-}$, and in the same way $\mathbf{5}^{2-}$ was synthesized.

- Synthesis of calixarene $6^{2-}$. The synthesis of $6^{2-}$ begins with the deprotonation of hydroxyl groups of starting calixarene $\mathbf{6}$ by $\mathrm{NaH}$, which was followed by $\mathbf{2}$ to give calixarene $\mathbf{6} \mathbf{a}^{2-}$. The reduction of two nitro groups of $\mathbf{6} \mathbf{a}^{2-}$ with hydrazine hydrate in the presence of Pd catalyst leads to $\mathbf{6 b}$ which by reaction with $\mathrm{NaH}$ followed by $\mathbf{E}$ yielded $\mathbf{6}^{2-}$.

2.1.2. Extraction properties of narrow rim substituted calixarenes $3^{-}, 4^{3-}, 5^{2-}$ and of the wide rim substituted calixarene $\mathbf{6}^{\mathbf{2}}$. The extraction experiments were performed for narrow rim substituted calixarenes $\mathbf{3}^{-}, \mathbf{4}^{3-}$ and $\mathbf{5}^{2-}$ in low polar solvent mixture consisting of hexyl methyl ketone (HMK) and hydrogenated tetrapropylene TPH (HMK/TPH 1:1 v/v); while for wide rim substituted calixarene $6^{2-}$ the hydrogenated tetrapropylene was replaced by $n$-dodecane.

In the evaluation of extraction properties of obtained calixarenes, the previously reported narrow rim substituted calixarenes $7^{2-}$ and $\mathbf{8}^{2-}$ of the $\mathrm{A}^{-}: \mathrm{B}$ ratio $2: 2$, and of their distal arrangement were used for comparison purposes. ${ }^{35}$

- Extraction properties of calixarenes $3^{-}, 4^{3-}, 5^{2-}$. It was found that the extraction efficiency at higher nitric acid concentration $(>1 \mathrm{M})$ decreases in the order: $7^{2-}>\mathbf{3}^{-}>\mathbf{5}^{2-}>>\mathbf{4}^{3-}$. This result shows that $\mathrm{A}: \mathrm{B}$ ratio $2: 2$ cannot be taken as the predominant factor enhancing the extraction efficiency, and that for the explanation of the influence on the extraction efficiency the mutual (adjacent or distal) arrangement of these groups should be also considered. Comparing extraction efficiency depending on the arrangement of $\mathrm{A}^{-}$and $\mathrm{B}$ in isomeric calixarenes $7^{2-}$ and $\mathbf{5}^{2-}$, both of the $\mathrm{A}^{-}: \mathrm{B}$ ratio $2: 2$, but for $7^{2-}$ in distal and for $\mathbf{5}^{2-}$ in adjacent arrangement, it was shown that it is higher for $7^{2-}$ than for $\mathbf{5}^{2-}$.

- Extraction properties of calixarene $6^{2-}$ Comparing extraction efficiency of wide rim substituted $6^{2-}$ with those of narrow rim substituted $7^{2-}$ and $\mathbf{8}^{2-}$, it was observed that the extraction efficiency decreases in the order $7^{2-}>8^{2-}>6^{2-36}$. This result contradicts the general observation of the higher extraction efficiency of wide rim substituted calixarenes than that of 
narrow rim substituted calixarenes. ${ }^{32}$ The contradiction is probably due to the fact that in $\mathbf{6}^{2-}$ the CMPO groups B are directly bound to the ipso positions of calixarenes, while in $7^{2-}$ and $\mathbf{8}^{2-}$ they are bound via the flexible butyloxy or ethyloxy chains, respectively (Scheme 1).
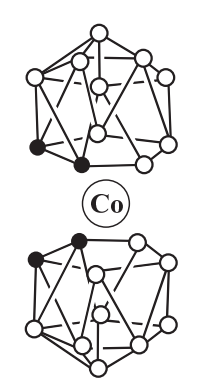

$1^{-}$

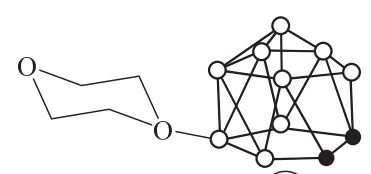

Co

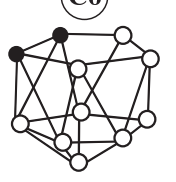

2

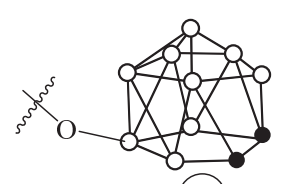

Co

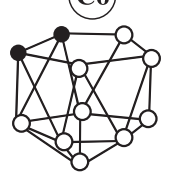

$\mathbf{A}^{-}$

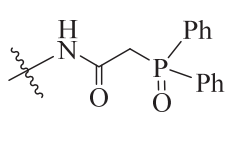

B cobalt bis(dicarbollide) ion dioxane derivative $\mathrm{O}=\mathrm{BH}$

- $=\mathrm{CH}$ of $\mathbf{1}^{-}$

for introduction of the anion $\mathrm{A}^{-}$ carbamoyl methyl diphenyl phosphine oxide group CMPO

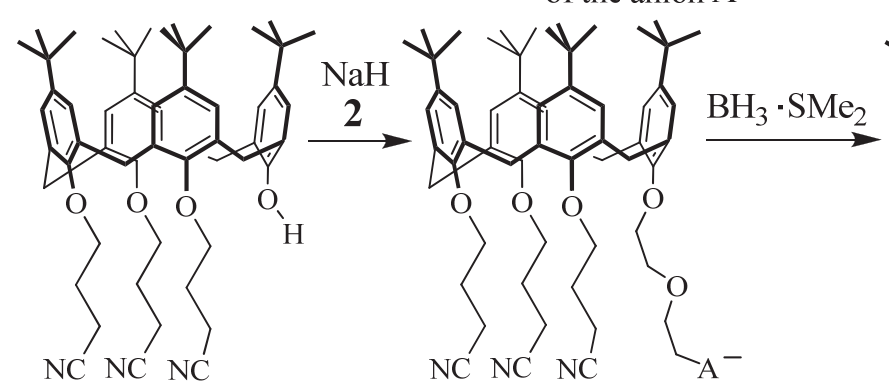

3

$3 \mathbf{a}^{-}$

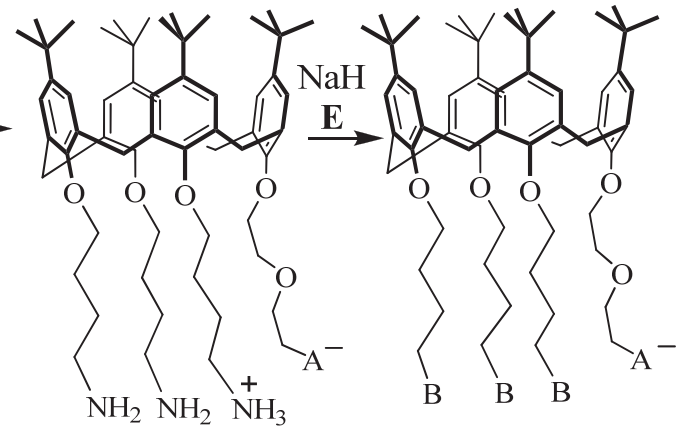

3b

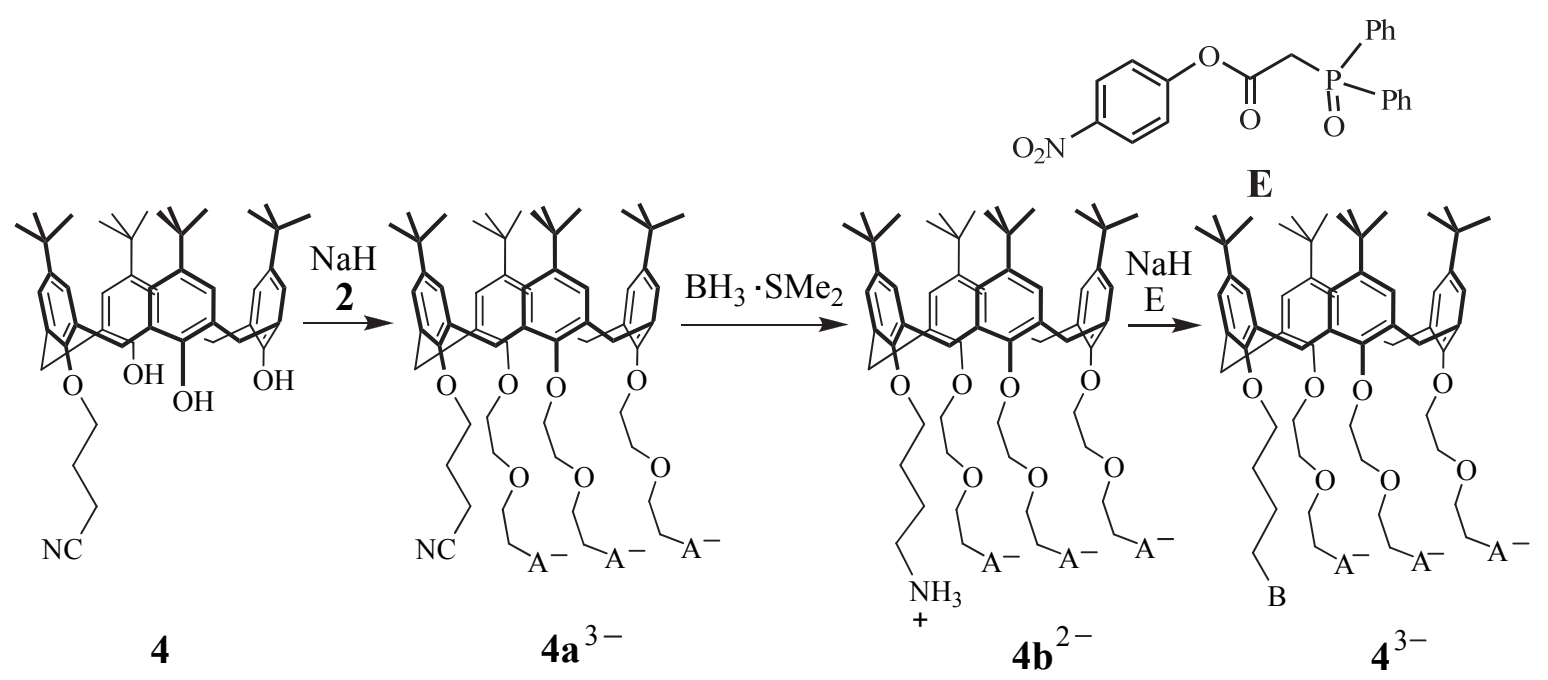

Scheme 1. To be continued 


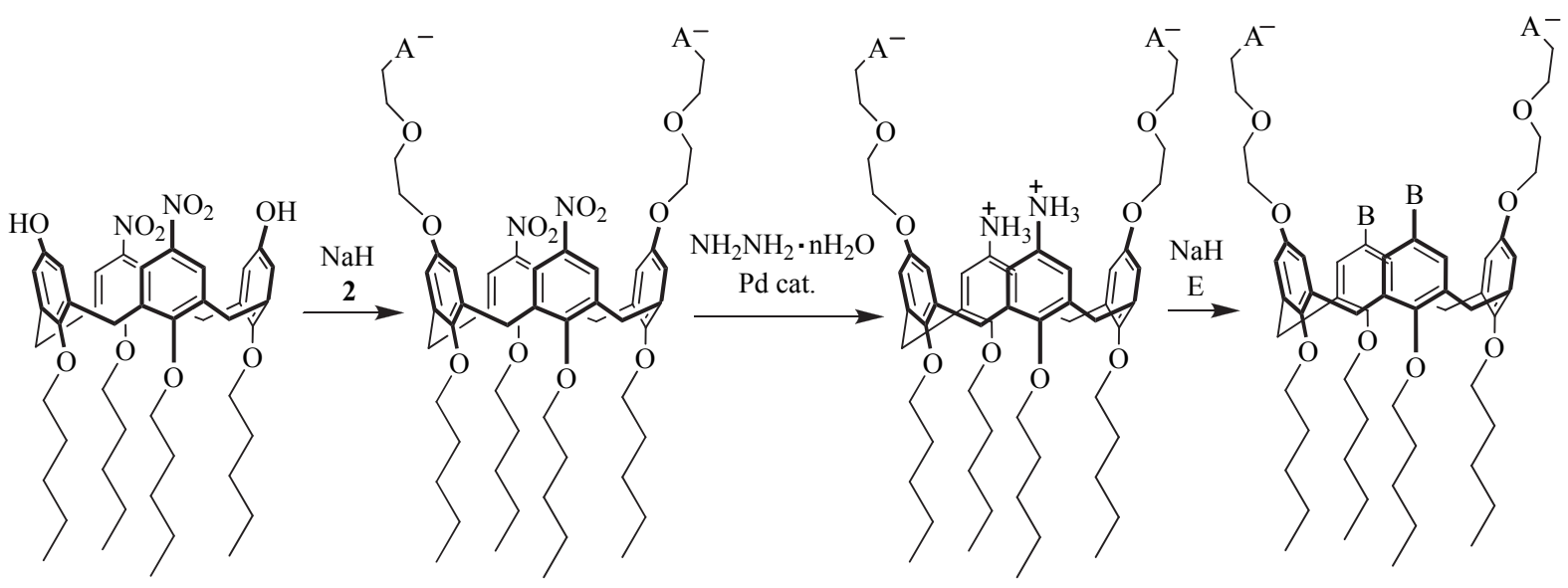

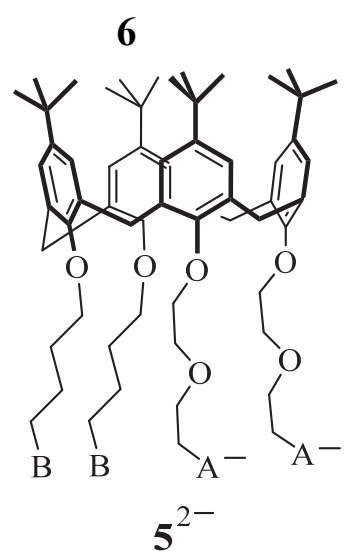

$\mathrm{AA}$ and $\mathrm{BB}$ groups mutually adjacent
$6 \mathbf{a}^{2-}$

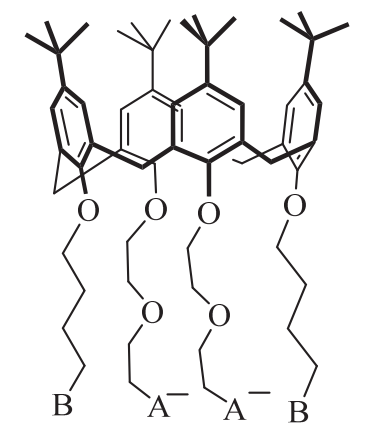

$7^{2-}$

$\mathrm{AA}$ and $\mathrm{BB}$ groups

mutually distal
$6 \mathbf{b}$

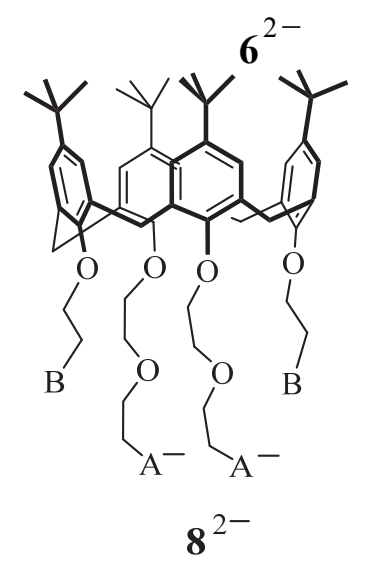

$\mathrm{AA}$ and $\mathrm{BB}$ groups

mutually distal

\section{Scheme 1}

\subsection{Extraction of uranium}

The naturally occurring radionuclides ${ }^{234} \mathrm{U},{ }^{235} \mathrm{U},{ }^{236} \mathrm{U}$ and belonging to the ${ }^{238} \mathrm{U}$ radioactive series ${ }^{210} \mathrm{Po}$ are dangerous to human health when ingested, and therefore their analysis is needed. $^{37}$

The calix[6]arene 9-based specific column AQUALIX ${ }^{38,39}$ was used for the separation and preconcentration of uranium in drinking water. This procedure was tested on French bottled waters. The method is suitable for routine analysis, it combines the separation on AQUALIX with fast ICP-MS (inductively coupled plasma mass spectrometry) measurement.

It should be pointed out the very good affinity and selectivity of $\mathbf{9}$ for uranium in the presence of high content of alkaline earth cations.

For water containing both uranium and polonium, the polonium radionuclides should be separated before the water loading on AQUALIX column. First the usual step of spontaneous deposition of polonium on silver disc is performed for separation of polonium, then the uranium extraction on AQUALIX column occurs, followed by alpha spectrometry counting. (Scheme 2) 


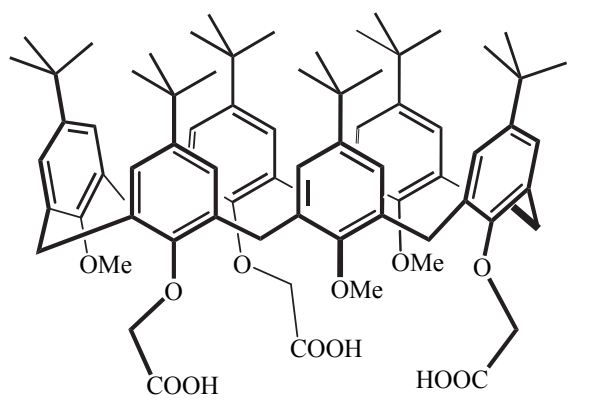

9 silica-functionalized quartz substrate

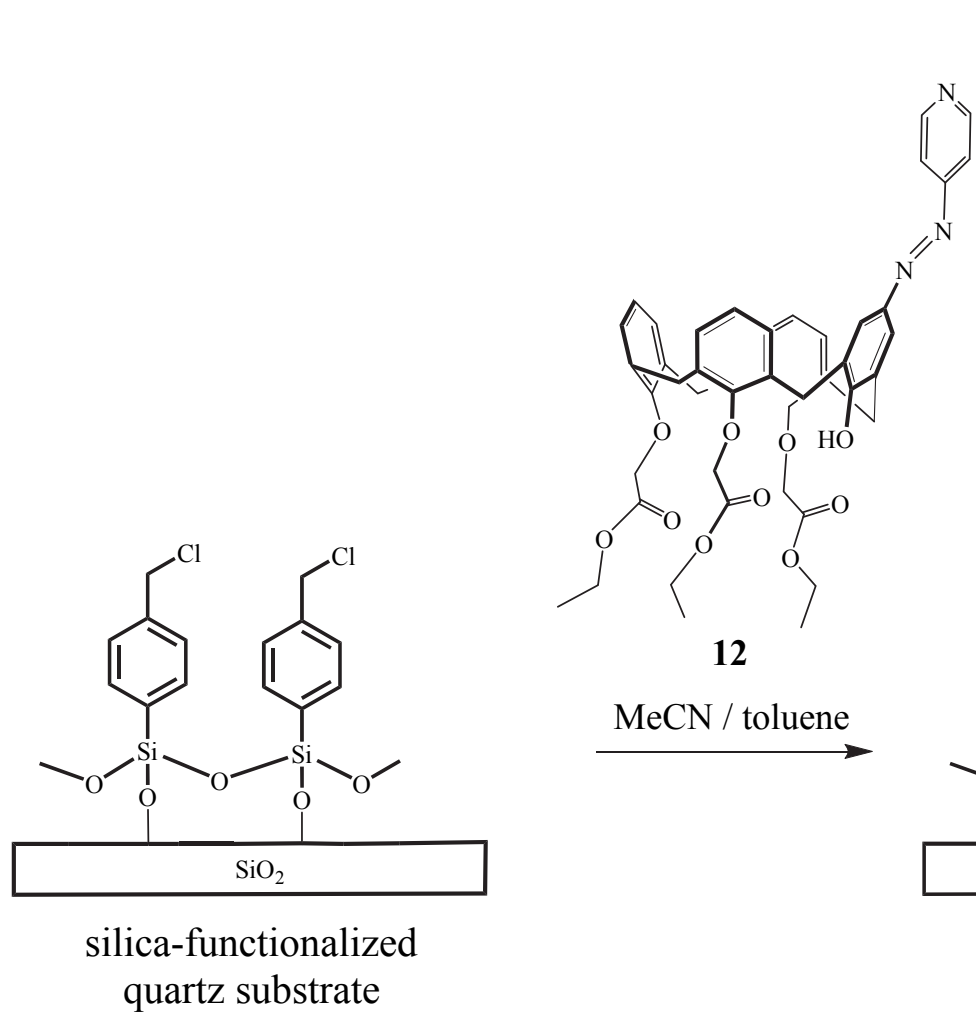

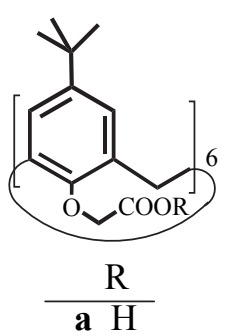

10 b Et c $t$-Bu

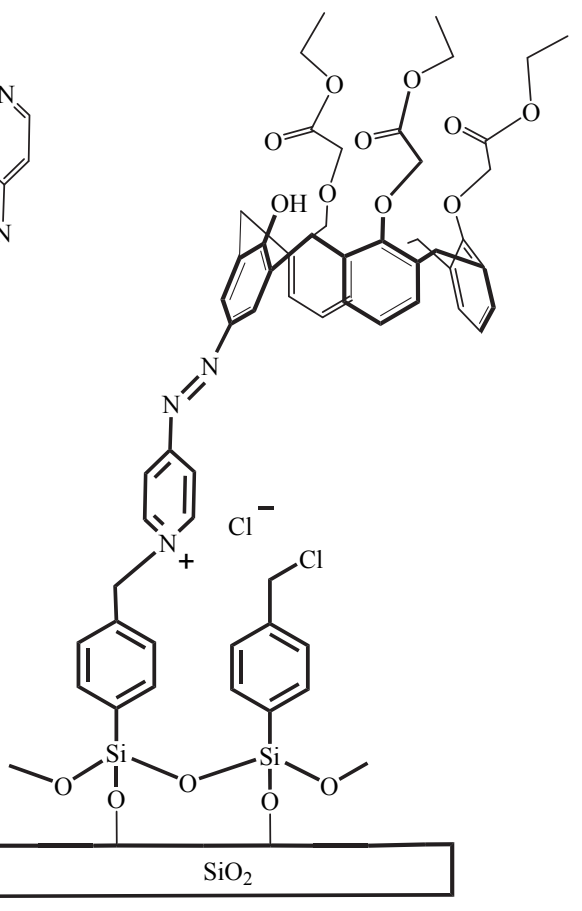

11

\section{Scheme 2}

\subsection{Sensing of $\mathrm{Pb}^{2+}$ and $\mathrm{Sr}^{2+}$ ions}

In the study of complexation of $p$-t-butylcalix[6]arenes 10a-c with metal ions, the properties of calix[6]arene 10a have been investigated. ${ }^{40}$ It is known that, in contrast to calix[4]arenes, having a thermodynamic preference for a rigid $\mathrm{C}_{4 \mathrm{v}}$ cone conformation, calix[6]arenes show a lower symmetry and are flexible, and their phenyl groups have alternating orientation in solution.

Calixarene 10b, even at low temperatures, has no identifiable conformation, but upon complexation with alkali metal ions changes it to the $\mathrm{C}_{6 \mathrm{v}}$ conformation. ${ }^{41}$ Calixarene 10c adopts a 1,2,3-alternate conformation in solution; however, upon complexation with $\mathrm{K}^{+}$and $\mathrm{Cs}^{+}$ions, it adopts the conformation $\mathrm{C}_{6 \mathrm{v}} \cdot{ }^{41}$ 
It was found that $p$-t-butylcalix[5] arene pentacarboxylic acid forms with $\mathrm{Pb}(\mathrm{II})$ a very strong complex of a cone conformation. ${ }^{42}$ To investigate the behavior of the higher order calix[6]arene, the complexation properties of $p$-t-butylcalix[6] arene hexacarboxylic acid 10a have been studied. The data of ${ }^{1} \mathrm{H}$ NMR analysis indicate for $\mathbf{1 0 a}$ the cone conformation in $\mathrm{CHCl}_{3}$, due to the presence of four hydrogen bond interactions among six carboxylic groups.

The experimental results show that $\mathbf{1 0 a}$ in $\mathrm{CHCl}_{3} / \mathrm{CH}_{3} \mathrm{CN}(1: 1)$ becomes conformationally flexible. In this solvent mixture $\mathbf{1 0 a}$ has a high affinity toward $\mathrm{Pb}^{2+}$ and instantly forms a strong complex of low symmetry; shortly thereafter the conformational reorganization occurs resulting in the stable, of a high symmetry complex of $\mathrm{Pb}^{2+}$ in an octahedral cage of carboxylates. ${ }^{43}$ Similar behavior has been observed for coordination of $\mathbf{1 0 a}$ with $\mathrm{Sr}^{2+}$ and $\mathrm{Ba}^{2+}$ ions, but the conformational reorganization is slower; the time period for achieving the conformational reorganization increases in the order $\mathrm{Pb}^{2+}<\mathrm{Sr}^{2+}<\mathrm{Ba}^{2+}$.

The above results are promising for the possible application of calixarene 10a in the removal of $\mathrm{Pb}^{2+}$ from the environment and in the removal of $\mathrm{Sr}^{2+}$ from nuclear wastes (Scheme 2).

\subsection{Sensing of $\mathrm{Li}^{+}$ions}

In view of wide industrial and medicinal application of lithium salts, ${ }^{44}$ the hybrid $\mathbf{1 1}$ consisting of calixarene $\mathbf{1 2}$ monolayer covalently immobilized on the silica-functionalized quartz substrate has been developed. ${ }^{45-47}$ The silylation of the quartz substrate was achieved by using 4$\mathrm{ClCH}_{2} \mathrm{C}_{6} \mathrm{H}_{4} \mathrm{SiCl}_{3}, \mathbf{1 3}$, which is a bifunctional coupling agent able to react by one side with the quartz surface, and by the other side with pyridyl group of 12. Upon the quaternization of pyridyl groups of 12 by chlorobenzyl groups of 13, the covalently bound hybrid $\mathbf{1 1}$ with an immobilized monolayer of a chromogenic sensing agent was obtained.

It has been found that the formed ionophore monolayer can reversibly recognize and bind lithium ions at ppm levels even in the presence of competitive $\mathrm{Na}^{+}$ions. The recognition of $\mathrm{Li}^{+}$ ions by hybrid 11 involves the formation of host-guest complex of $\mathrm{Li}^{+}$ion in the cavity of $\mathbf{1 2}$. The X-ray photoelectron spectroscopy and UV/Vis study have shown that this system is a useful optical device for the detection of lithium ions. Hybrid $\mathbf{1 1}$ is thermally stable and able for a longterm storage; it may be used as an on/off optical control device for lithium ions by the fast readout procedures. One should note that the formed monolayer is highly reproducible by the aqueous acid reactivation (Scheme 2).

\subsection{Sensing of $\mathrm{Al}^{3+}$ ions}

Aluminum is widely used in medicine and plays an important role in the human organism ${ }^{48}$ and therefore the determination of trace $\mathrm{Al}^{3+}$ ions is necessary. An optical chemical sensor (optode) based on azocalix[4]arene $\mathbf{1 4}$ has been prepared for the determination of $\mathrm{Al}^{3+}$ ions in aqueous solutions. ${ }^{49}$ It was established that $\mathbf{1 4}$ shows high sensitivity and selectivity toward $\mathrm{Al}^{3+}$ ion. ${ }^{50}$ The cation-binding properties and the stability constants for $1: 1$ complex of 14 with $\mathrm{Al}^{3+}$ ion were determined in acetonitrile solution by spectrophotometric methods. 
The optode sensing film was prepared by spin-coating technique on glass plates. The optical sensor displays a linear response to $\mathrm{Al}^{3+}$ over $10^{-7}-10^{-9} \mathrm{M}$. It is noteworthy that the optical sensor has high stability and can be regenerated with nitric acid (Scheme 3).

\subsection{Sensing of $\mathrm{Ni}^{2+}$ and $\mathrm{Hg}^{2+}$ ions}

Calix[4]arene Schiff bases 15a-e were investigated in view of their metal ions complexation; they were synthesized by reacting diaminocalixarenes with appropriate aldehydes. ${ }^{51}$

The abilities of 15a-e to extract selected metal ions from an aqueous into an organic phase have been evaluated by picrate extraction experiments. It was found that $\mathbf{1 5 c}$ shows high selectivity towards $\mathrm{Ni}^{2+}$, and compounds $\mathbf{1 5 a}, \mathbf{d}, \mathbf{e}$ show high selectivity towards $\mathrm{Hg}^{2+}$. Compound $\mathbf{1 5 b}$ is highly efficient for the extraction of $\mathrm{Ni}^{2+}, \mathrm{Co}^{2+}, \mathrm{Cu}^{2+}, \mathrm{Ag}^{+}, \mathrm{Pb}^{2+}, \mathrm{Cd}^{2+}$ and $\mathrm{Hg}^{2+}$ ions (Scheme 3).

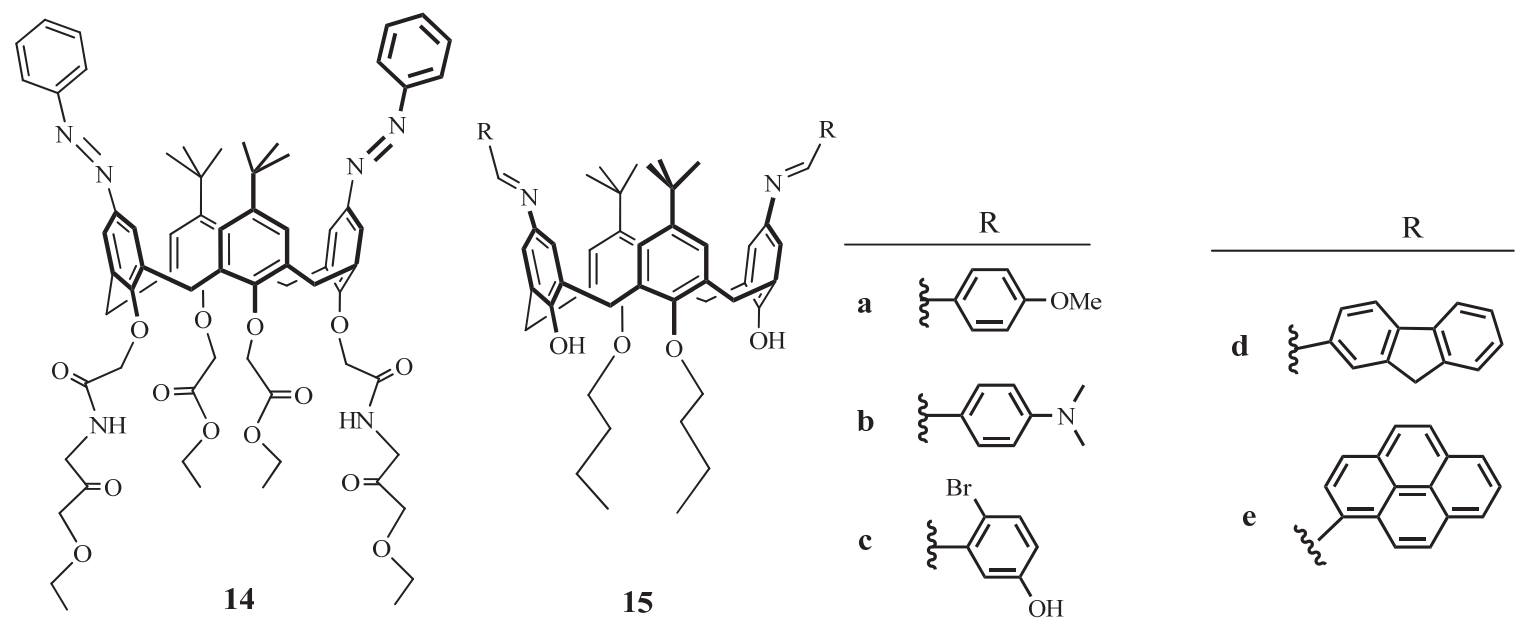

\section{Scheme 3}

\subsection{Sensing of $\mathrm{Cr}_{2} \mathrm{O}_{7}{ }^{2-}$ and $\mathrm{HCr}_{2} \mathrm{O}_{7}^{-}$ions}

It is known that dichromate oxoanions are highly toxic. ${ }^{52}$ Chromium and its derivatives are transmitted to groundwater in trivalent and hexavalent forms, and their influence on the environment is significant. ${ }^{53,54}$ The trivalent form $\mathrm{Cr}$ (III) is important for mammals in maintaining glucose, lipid and protein metabolisms, however the hexavalent form, $\mathrm{Cr}(\mathrm{VI})$ is toxic, e.g. it can diffuse as $\mathrm{Cr}_{2} \mathrm{O}_{7}^{2-}$ or $\mathrm{HCr}_{2} \mathrm{O}_{7}^{-}$through human cell membranes, resulting in oxidized biological molecules. ${ }^{53,55}$

Because $\mathrm{Cr}(\mathrm{VI})$ is a strong environmental pollutant, ${ }^{55}$ for its removal from contaminated water a variety of separation techniques, e.g. nanofiltration, solvent extraction and adsorbing colloid flotation have been used. ${ }^{56-58}$

In the experiments the anion extraction properties of "proton-switchable" calix[4]arene 16 bearing terpyridine moieties have been investigated. ${ }^{59}$ This compound is obtained in the reaction of calixarene 17 with the bromoderivative 18 in $\mathrm{MeCN}$. The study of 2,2':6:2"-terpyridine and 
its derivatives has been widely performed in various areas. Their luminescent properties allow the fluorescent recognition of a target; it is also of interest that the pyridine nitrogen atoms may coordinate with transition metal ions.

The extraction ability of $\mathbf{1 6}$ for the dichromate, regarding its removal from aqueous solutions was discussed in a liquid-liquid extraction system. For the extraction study of 16, the mixture of $\mathrm{CH}_{2} \mathrm{Cl}_{2}$ solution of $\mathbf{1 6}$ with aqueous solution of $\mathrm{Na}_{2} \mathrm{Cr}_{2} \mathrm{O}_{7}$ was shaken. It was found that the $\mathrm{pH}$ value of dichromate anions is important in the extraction process and that $\mathbf{1 6}$ is partially protonated under acidic conditions. Under acidic conditions $\mathrm{Na}_{2} \mathrm{Cr}_{2} \mathrm{O}_{7}$ is transformed into $\mathrm{H}_{2} \mathrm{Cr}_{2} \mathrm{O}_{7}$, and the ionization in an aqueous solution leads to $\mathrm{HCr}_{2} \mathrm{O}_{7}{ }^{-} / \mathrm{Cr}_{2} \mathrm{O}_{7}{ }^{2-}$, these both dimers being dominant. ${ }^{55}$ The dichromate extraction results have shown that $\mathbf{1 6}$ has high complexation efficiency at $\mathrm{pH}$ 1.5, affording $\mathbf{1 6} \supset \mathrm{HCr}_{2} \mathrm{O}_{7}{ }^{-}$.

In the above investigations it was established that the complexation efficiency of dichromate anions depends on the hydrogen-binding ability and proton-switchable ability of calixarene. The obtained results have shown that $\mathbf{1 6}$ is promising for the removal of dichromate anions from environmental aqueous solutions (Scheme 4).

\subsection{Sensing of $o$ - and $p$-nitrophenols}

Palladium-catalyzed Sonogashira cross-coupling reactions are very important in syntheses of fluorescent calixarenes which combine properties of ionophores and fluorophores. This method was used for coupling of calixarene 19 with para-substituted iodobenzene, affording calixarene derivatives 20a-c. ${ }^{60}$

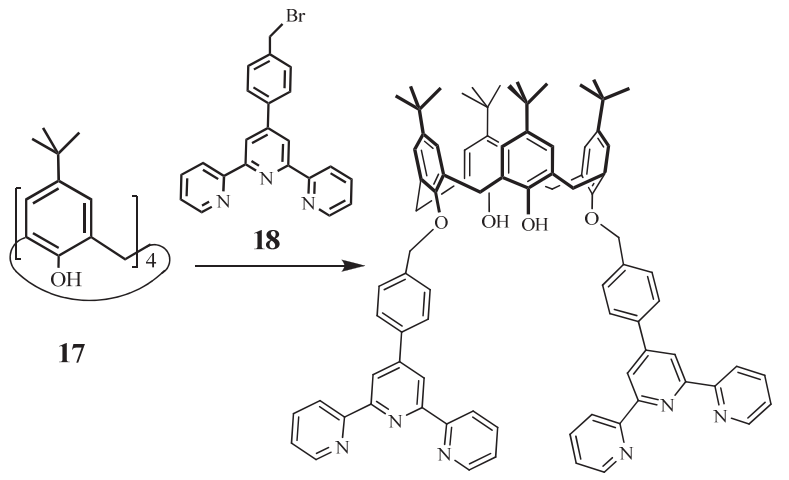

16

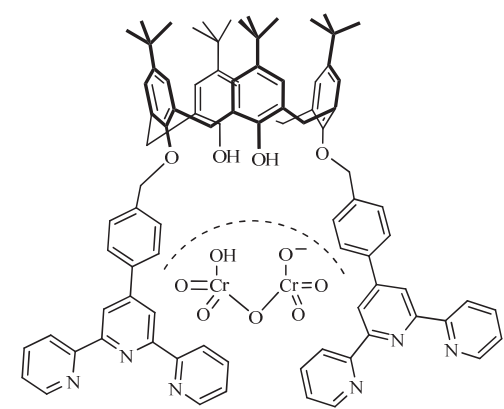

16) $\mathrm{HCr}_{2} \mathrm{O}_{7}^{-}$

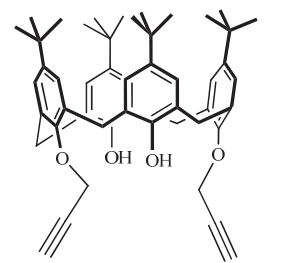

19

\section{Scheme 4}

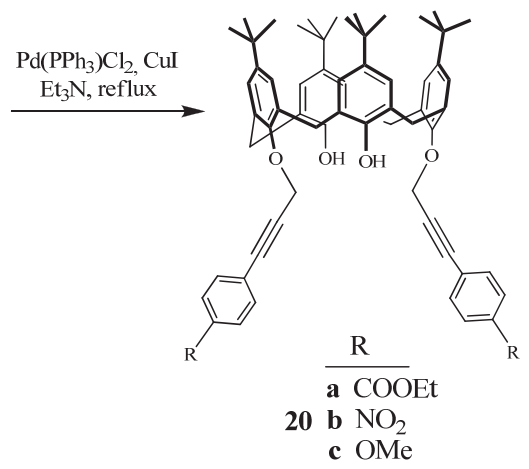


It was observed that the calixarene 20c has a high binding affinity to nitrophenols since its fluorescence is strongly quenched by $o$ - and $p$-nitrophenols. The computational calculations of the complex of 20c with $p$-nitrophenol have shown that the $\pi$ - $\pi$ stacking occurring between 20c and $p$-nitrophenol forms a tweezer structure, which leads to electron transfer and results in the fluorescence quenching of $\mathbf{2 0 \mathbf { c } ^ { 6 1 }}$ (Scheme 4).

\section{Other applications of calixarenes}

\subsection{Bodipy-based photosensitizer with PEGylated calixarene as a carrier}

Today photodynamic therapy (PDT) ${ }^{62}$ has been developed as a less invasive alternative to traditional therapeutic methods such as surgery or chemotherapy. In PDT procedure the light, singlet oxygen and a photosensitizer are necessary, therefore recently many reports concern the search for new photosensitizers. ${ }^{63}$

In PDT porphyrins and their derivatives are used as photosensitizers, but they have relatively weak absorption in the red region of the visible spectrum, where mammalian tissues are most transparent. ${ }^{64}$ Therefore dyes having strong absorption in the IR and near IR region of the spectrum are needed.

Bodipy dyes are promising as photosensitizers. ${ }^{64,65}$ It was found that Bodipy dyes can be transformed into efficient photosensitizers by incorporation of heavy atoms ${ }^{66}$ or by increasing the degeneracy of the excited state frontier orbitals. ${ }^{67}$ The results of performed experiments have shown that the water soluble, amphiphilic calixarene $\mathbf{2 1}$ may serve as a photosensitizer. ${ }^{68}$ The synthesis of 19 begins with the reaction of the partially $t$-butylated calixarene $22^{69}$ with 1 bromodecane affording the tetradecylated product which without isolation was formylated with hexamethylenetetramine (HMTA) to give calixarene 23.

Calixarene 23 upon Knoevenagel condensation with intermediate $\mathbf{2 4}$ yielded calixarene bearing two Bodipy dyes. This compound reacted in situ with 4-(dimethylamino)benzaldehyde to give calixarene 25. The treatment of $\mathbf{2 5}$ with methoxypolyethyleneglycol azide PEG-N $\mathrm{N}_{3}$ afforded by azide-alkyne Huisgen cycloaddition ("click" reaction) the Bodipy-based photosensitizer 21 with PEGylated calixarene as a carrier.

The photosensitizer 21 containing heavy iodine atoms undergoes rapid intersystem crossing to generate singlet oxygen, which is used in PDT. Two Bodipy units are tethered to a calixarene core, and this reaction extends the conjugation so that the absorption of Bodipy dye is within the so-called "therapeutic window". (Scheme 5)

The functionalization of calixarene with two Bodipy chromophores with strong intersystem crossing tendency results from the presence of heavy iodine atoms attached to the Bodipy core. The long chain alkyl substituents on the narrow rim provide some hydrophobic character, and the two PEG chains on the wide rim ensure the water solubility, in this way creating the amphiphilic photosensitizer. It is noteworthy that the presence of styryl substitution allows the near IR absorption. The above described calixarenes are promising for applications as singlet oxygen carriers and as delivery agents. 

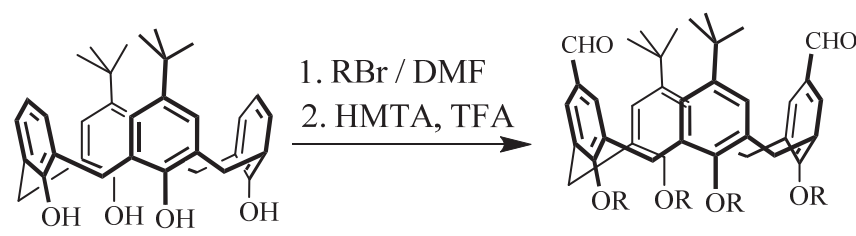

22

$\mathrm{R}=\mathrm{C}_{10} \mathrm{H}_{21}$

HMTA $=$ hexamethylenetetramine
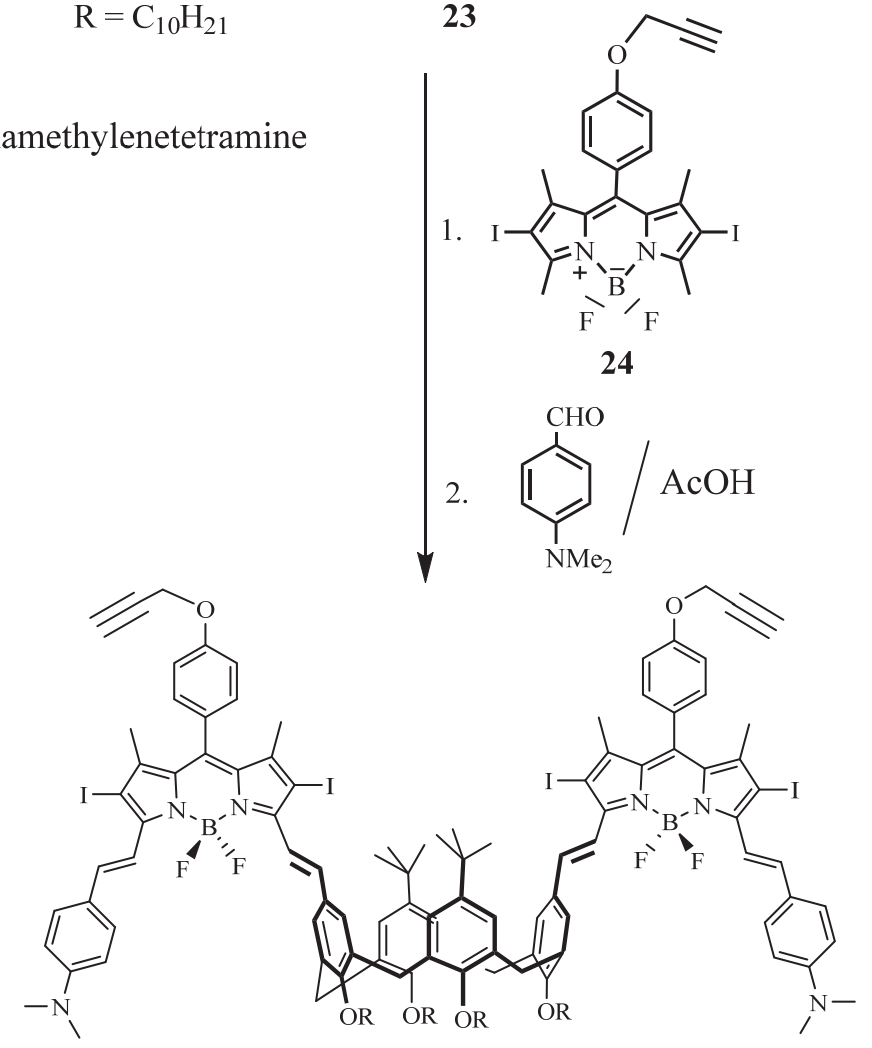

25
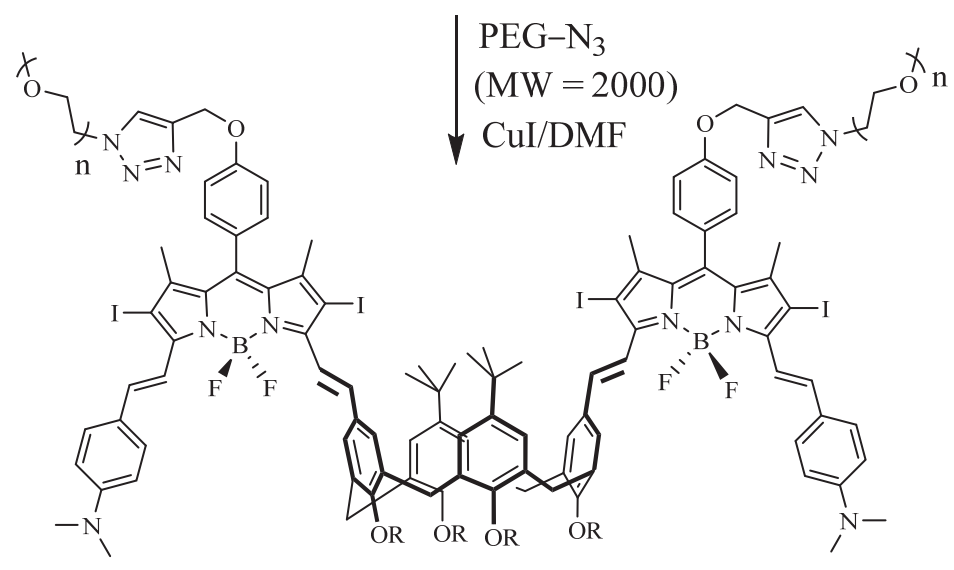

21

$\mathrm{R}=\mathrm{C}_{10} \mathrm{H}_{21} ; \mathrm{n} \cong 45$

Scheme 5 


\subsection{Recovery of butanol from dilute aqueous solutions with the use of immobilized calixarenes}

The increasing cost of oil has resulted in recent years in an interest in acetone/butanol/ethanol (ABE) fermentation for the production of $n$-butanol as an alternative fuel. Butanol has good mixing properties with other fuels and its octane number is similar to that of gasoline.

However, a drawback of the ABE fermentation is the separation of products from the dilute aqueous solution. Having in view this difficulty, along with the high boiling point of butanol, ${ }^{70}$ and the presence of other compounds, the effective separation and recovery methods are necessary for the $\mathrm{ABE}$ fermentation. For this purpose a step preceding the distillation, which would be able to concentrate the products more efficiently than distillation should be useful, and as such a step the separation techniques were chosen. A variety of these techniques are available, e.g.in situ vacuum recovery ${ }^{71}$ or osmosis, ${ }^{72}$ but adsorption was shown to be the most convenient procedure.

For the adsorption, a number of materials were investigated, among them activated carbons, zeolites, silicas and polymers. Materials based on silica may undergo many surface modifications; in the reported method of dilute aqueous acetone, butanol and ethanol recovery, the silica surfaces were modified by immobilized calixarenes, where each calixarene molecule served as a single adsorption site.

The previous work concerned the use of silica-immobilized calixarenes which contained hydrophobic groups at the wide rim acting as adsorption sites for butanol from dilute aqueous solution. ${ }^{73}$ Adsorption on these materials involved the exchange of solvent water molecules for adsorbate molecule within the calixarene cavity. For such hydrophobic calixarenes $(\mathrm{R}=\mathrm{H}$ or alkyl) the adsorption is driven by weak intermolecular van der Waals forces.

In the continuation of the above experiments, the silica-immobilized calixarenes were also used as adsorption sites, but their wide rim contained additionally the strongly electron withdrawing groups such as $-\mathrm{NO}_{2}$ or $-\mathrm{Br}$ to study the influence of polarization of the cavity. ${ }^{74}$ Besides $t$-butanol, the adsorption of acetone and ethanol was also investigated for their smaller size and possibility for stronger dipole-dipole interaction with calixarene cavities.

In this process, first $\mathrm{H}-\mathrm{SiO}_{2} 26$ was treated with $\mathrm{SiCl}_{4}$, followed by $\mathrm{Et}_{3} \mathrm{~N}$ to give $\mathrm{Cl}_{3} \mathrm{Si}_{-}-\mathrm{SiO}_{2}$, i.e. the chlorinated $\mathrm{SiO}_{2}$ 27. The reaction of 27 with toluene solution of calixarene 28a-d afforded $\mathbf{2 8}-\mathrm{SiO}_{2}$, i.e. silica - immobilized calixarene 29a-d.

The investigations showed that ethanol and butanol insert their alkyl chains into calixarene cavities. This behavior enables the interaction of alcohol hydroxyl groups with solvent water molecules via hydrogen bonding, while allowing their hydrophobic chains to desolvate from water. ${ }^{75}$

It has been observed that 29a was the strongest adsorbent among other calixarenes; this fact is compatible with study of water soluble calixarenes, showing that the more hydrophobic surface area of the host leads to a stronger overall interaction. ${ }^{76}$ (Scheme 6) 


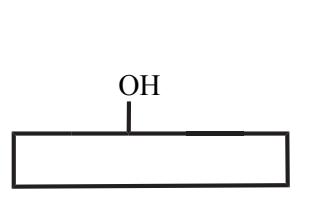

26
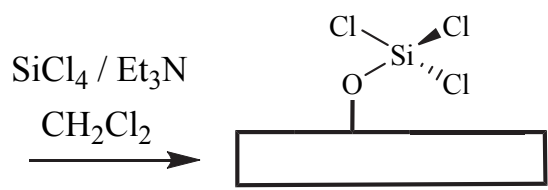

27

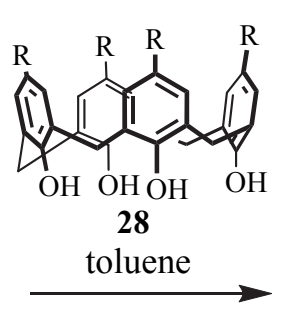

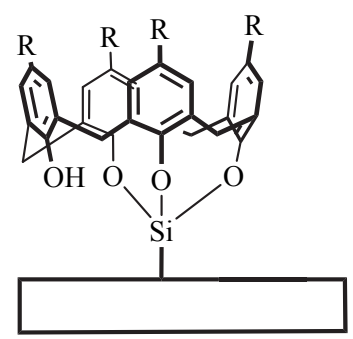

28- $-\mathrm{SiO}_{2}=\mathbf{2 9}$

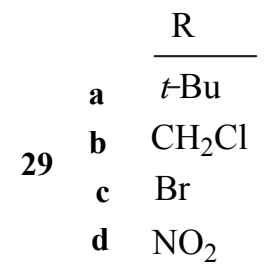<smiles>CCNc1nc(Cl)nc(NCC)n1</smiles>

30<smiles>CCNc1nc(Cl)nc(NC(C)C)n1</smiles>

atrazine

31<smiles>CCNc1nc(Cl)nc(NC(C)(C)C#N)n1</smiles>

cyanazine

32

\section{Scheme 6}

The correlation between molecular surface area and adsorption strength of alkyl calixarenes was reported. $^{73}$ To find an analogous relationship between calixarene polarity and adsorption strength, the Hammett constants were used. The computational results indicate that the cavity dehydration is the strongest driving force behind host-guest complexation in water. ${ }^{77}$ Therefore it has been established that the presence of electron withdrawing functional groups at wide rim of calixarenes may lead to their strong interactions with water molecules, either via dipole-dipole attraction or via $\mathrm{OH}-\pi$ bonds.

The above study shows that the silica-supported calixarenes may serve as adsorbents for aqueous organics, and may be used to biofuel separations from dilute aqueous fermentation broth. Due to calixarene cavities and their highly dispersed nature on the hydrophilic support, calixarenes (which are by themselves insoluble in water without modifications), are forcibly hydrated. This fact allows to investigate calixarenes in water without adding solubilizing groups, such as sulfonates or carboxylates. The obtained results help to elucidate the nature of interactions between hydrophobic calixarene cavities and guests in water.

\subsection{Calixarene-coated solid-phase microextraction fibres}

Triazines 30-32 are widely used herbicides, in agricultural crops like corn or wheat as well as in the roadside verges. It is known, however, that triazines and their degradation products are toxic 
and very resistant, being able to survive many years in the soil. Due to their low absorption in soil, the triazine herbicides easily migrate through soil into the surface and ground water. Therefore the use of triazines is restricted, and in view of this the need for the determination of trace amounts of triazines becomes apparent.

In trace analysis, in many fields, e.g. pharmaceutical, ${ }^{78}$ food $^{79}$ or biochemistry ${ }^{80}$ solid-phase microextraction (SPME) is used. This is an efficient extraction technique enabling simultaneous extraction and preconcentration of aqueous, gaseous and solid matrices. SPME may be coupled with various technologies, e.g. gas chromatography $(\mathrm{GC})^{81}$ or GC-mass spectrometry (GCMS). ${ }^{82}$

To sorbent materials in SPME belong such coatings as polydimethylsiloxane (PDMS), polyacrylate $(\mathrm{PA})$ or carbowax $(\mathrm{CW}) .{ }^{83}$ These commercial coatings, however, are relatively expensive and difficult to be prepared in a routine laboratory due to their poor extraction reproducibility. ${ }^{84}$

In the search for novel, low cost coating materials for SPME, enabling a better sensitivity and selectivity of this procedure, the calixarene 17-coated SPME fibre has been prepared on the surface of the quartz fibre by the sol-gel method. ${ }^{85}$ This fibre was used for the monitoring of triazines in fruit and vegetables.

To immobilize organic polymers on the quartz fibre, the chemical bonding of the polymer coating to the quartz fibre surface was made by the sol-gel method. Prior to sol-gel coating, the quartz fibre was dipped in $1 \mathrm{~mol} \mathrm{~L}^{-1} \mathrm{NaOH}$ solution to expose the silanol groups on the surface. Then the fibre was silylated by immersing into 3-(methacryloyloxy) propyltrimethoxysilane solution in acetone.

For preparation of a sol solution, first the hydroxylterminated silicone oil (OH-TSO), tetraethoxysilane (TEOS) and poly(methylhydrosiloxane (PMHS) were dissolved in acetone. To this solution the calixarene $\mathbf{1 7}$ dissolved in the ionic liquid (IL), namely 1-vinyl-3butylimidazolium difluoromethyl sulfimide was added. The fibre treated wit this sol solution, after formation of sol-gel coating was used for the determination of triazines (simazine, atrazine and cyanazine) in fruit and vegetable samples. ${ }^{86}$ (Scheme 6)

It was found that the calixarene 17-coated fibres are homogeneous and dense, therefore a good reproducibility can be achieved for their preparation. One should note that these fibres are stable, and their multiple use is possible. The above method is simple and fast, and proved to be an efficient and sensitive procedure for monitoring of triazines in fruit and vegetables.

\subsection{Calixarene-supported lanthanide single-molecule magnet}

Single-molecule magnets (SMMs) are interesting for their physical properties involving quantum tunneling of magnetization and possible applications in nanoscale electronic devices. The design of SMMs with lanthanide ions is recently developing due to the significant magnetic anisotropy resulting from their large orbital angular momentum. ${ }^{87,88}$ The family of single lanthanide-based molecular magnets consists of mononuclear systems in which single lanthanide ion is situated in an effective crystal field. ${ }^{89-91}$ 


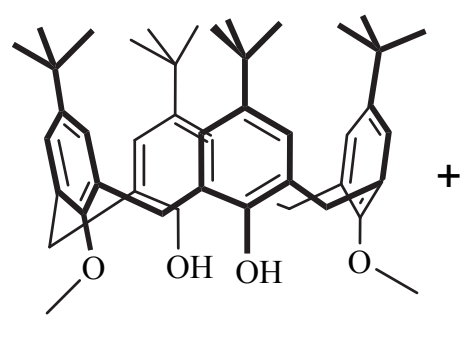

$\mathrm{H}_{2} \mathrm{~L}$

34

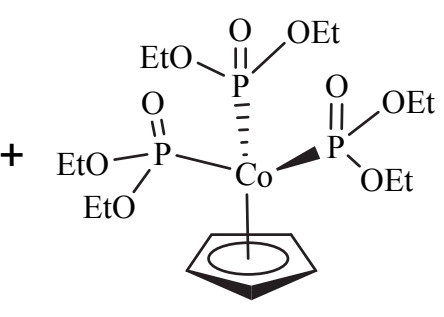

$\mathrm{L}^{-}$OEt

35

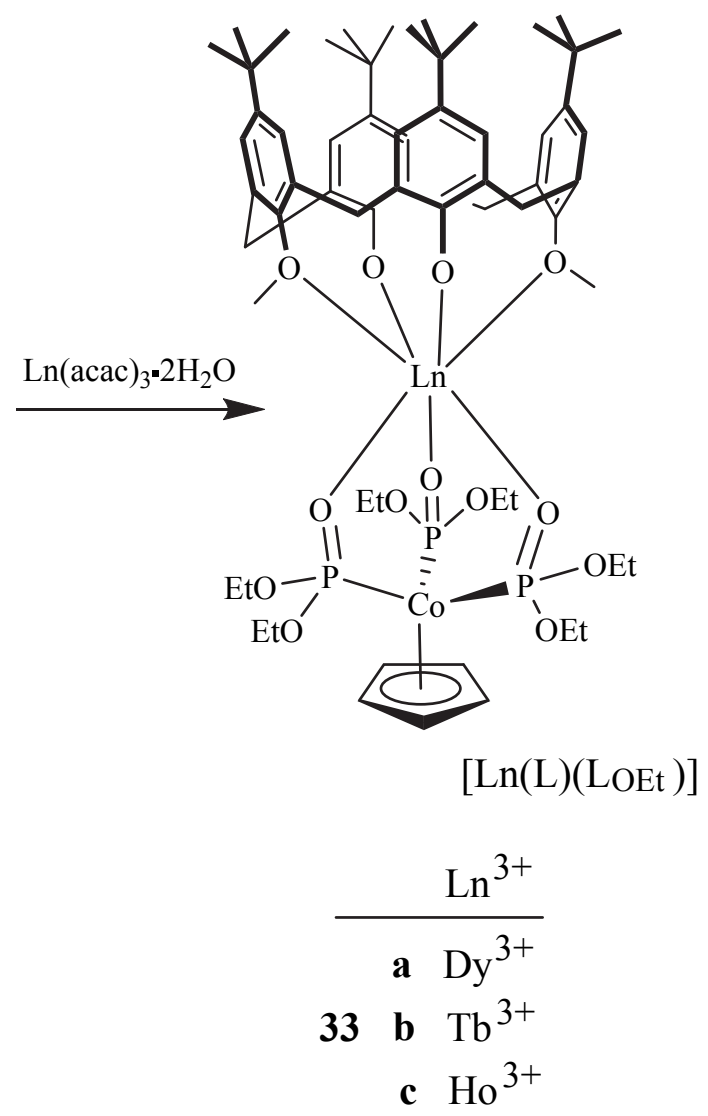

\section{Scheme 7}

Three lanthanide complexes 33a-c $\left[\mathrm{Ln}(\mathrm{L})\left(\mathrm{L}_{\mathrm{OEt}}\right)\right]$, where $\mathrm{Ln}^{3+}=\mathrm{Dy}^{3+}(\mathbf{a}), \mathrm{Tb}^{3+}(\mathbf{b})$ and $\mathrm{Ho}^{3+}(\mathbf{c})$ were synthesized from calixarene $\mathrm{H}_{2} \mathrm{~L} 34$, Kläui's tripodal ligand $\mathrm{NaL}_{\mathrm{OEt}} 35$ and lanthanide acetylacetonate. $^{92}$ The bulky calixarene and tripodal ligands effectively encapsulate the paramagnetic lanthanide ion, shielding it from interactions with the environment. It was found that the dysprosium complex 33a shows SMM behavior with characteristic magnetic hysteresis loops and slow relaxation of magnetization; it is calixarene-supported lanthanide single molecule magnet. (Scheme 7) The above investigations are promising for tuning magnetic properties of lanthanide complexes.

\section{Conclusions}

The number of reports on calixarenes is enormous, ${ }^{93-98}$ they show results of theoretical studies, as well as practical applications of these compounds. Therefore an exhaustive presentation of studies dealing with calixarenes would be impossible, and in the review only selected examples are described. 
One ought to pay attention to an increasing number of works concerning application of calixarenes in the biological ${ }^{99,100}$ and pharmaceutical fields, ${ }^{5,6}$ and as a result one may expect further progress in these wide and important research areas. It is noteworthy that the applications of calixarenes are diversified; one may mention here the preparation of calixarene-based ionic liquids, ${ }^{101,102}$ and formation of metal NPs, ${ }^{103,104}$ today intensively studied.

Although due to the large amount of works dealing with calixarenes, ${ }^{105-110}$ in this review only selected examples are presented, one might hope that the recent reports here cited will help towards a better understanding of this interesting field of chemistry and related sciences.

\section{References}

1. Baldini, L.; Sansone, F.; Casnati, A.; Ungaro, R. Calixarenes in molecular recognition. Supramolecular Chemistry: From Molecules to Nanomaterials 2012, 3, 863.

2. Gutsche, C.D. Calixarenes, an Introducton, Monographs in Supramolecular Chemistry, Royal Society of Chemistry, London, 2008.

3. Savithri, A.; Thulasi, S.; Varma, R. L. J. Org. Chem. 2014, 79, 1683.

http://dx.doi.org/10.1021/jo4025732

4. Costa, P. J.; Marques, I.; Felix, V. Biochim. Biophys. Acta, Biomembranes 2014, 1838, 890.

5. El-Sayed, M. A. Sens. Actuators, B 2014, 190,101.

http://dx.doi.org/10.1016/j.snb.2013.08.065

6. Nasuhi Pur, F.; Dilmaghani, K. A. J. Coord. Chem. 2014, 67, 440.

http://dx.doi.org/10.1080/00958972.2014.890718

7. Tulli, L. G.; Moridi, N.; Wang, W.; Helttunen, K.; Neuburger, M.; Vaknin, D.; Meier, W.; Shahgaldian, P. Chem. Comm. 2014, 50, 3938.

\section{http://dx.doi.org/10.1039/c4cc00928b}

8. Maity, D.; Gupta, R.; Gunupuru, R.; Srivastava, D. N.; Paul, P. Sens. Actuators, B, Chem. 2014, 191, 757.

9. Pulkkinen, P. M. S.; Hassinen, J.; Robin, H.A.; Tenhu, H. RSC Advances 2014, 4, 13453. http://dx.doi.org/10.1039/c4ra00494a

10. Ruitao, Z.; Shileng, T.; Srinivasan, M. P. Thin Solid Films 2014, 550, 210. http://dx.doi.org/10.1016/j.tsf.2013.10.161

11. Jiang, B.-P.; Guo, D.-S.; Liu Y.-C.; Wang, K.-P.; Liu, Y. ACS Nano 2014, 8, 1609. http://dx.doi.org/10.1021/nn405923b

12. Montmeat,P.; Veignal, F.; Methivier, C.; Pradler, C.M.; Hairault, L. Appl. Surf. Sci.2014, $292,137$.

http://dx.doi.org/10.1016/j.apsusc.2013.11.101

13. Yang, C.; Liu, T.; Xu, Y.; Qin, Y. Sens. Actuators, B, Chem. 2014, 192, 423.

14. Mokhthari, B.; Pourabdollah, K. Asian J. Chem. 2013, 25, 1. 
15. Chu, H.; He, L.; Jiang, Q.; Fang, Y.; Jia, Y.; Yuan, X.; Zou, S.; Li, X.; Feng, W.; Yang, Y.; Liu, N.; Luo, S.; Yang, Y.; Yang, L.; Yuan, L. J. Hazard. Mater. 2014, 264, 211. http://dx.doi.org/10.1016/j.jhazmat.2013.11.021

16. Huang, H.; Ding, S.; Liu, N.; Wu, Y.; Su, D.; Huang, S. Sep. Purif. Technol. 2014, 123, 235. http://dx.doi.org/10.1016/j.seppur.2013.12.039

17. Deska, M.; Sliwa, W. Covalently and Noncovalently Bound Assemblies of Calixarenes, Nova Science Publishers Inc: New York, 2011.

18. Sliwa, W; Deska, M. Arkivoc 2011, (1), 496. http://dx.doi.org/10.3998/ark.5550190.0012.110

19. Sliwa, W; Deska, M. Arkivoc 2012, (1),173. http://dx.doi.org/10.3998/ark.5550190.0013.106

20. Sliwa, T.; Girek, T. J. Incl. Phenom. Macrocycl. Chem. 2010, 66, 15. http://dx.doi.org/10.1007/s10847-009-9678-7

21. Sliwa, W.; Kozłowski, C. Calixarenes and Resorcinarenes, Wiley-VCH: Weinheim, 2009.

22. Deska, M.; Dondela, B.; Sliwa, W. Arkivoc 2014, (1) 29. http://dx.doi.org/10.3998/ark.5550190.p008.753

23. Poms, D.; Itzhak, N.; Kuno, L.; Biali, S. E. J. Org. Chem. 2014, 79, 538. http://dx.doi.org/10.1021/jo402223x

24. Fischer, C.; Lin, G.; Seichter, W.; Weber, E. Tetrahedron Lett. 2013, 54, 2187. http://dx.doi.org/10.1016/j.tetlet.2013.02.061

25. Predeus, A. V.; Gopalsamuthiram, V.; Staples, R. J.;Wulff, W. D. Angew. Chem. Int. Ed. 2014, 67, 911.

26. Sawada, T.; Hongo, T.; Matsuo, N.; Konishi, M.; Kawaguchi, T. Ihara, H. Tetrahedron 2011, 67, 4716. http://dx.doi.org/10.1016/j.tet.2011.04.025

27. Kubat, P.; Sebera, J.; Zalis, S.; Langmaier, J.; Fuciman, M.; Polivka, T.; Lang, K. Phys. Chem. Chem. Phys. 2011, 13, 6947. http://dx.doi.org/10.1039/c0cp01726d

28. Roales, J.; Pedrosa, J. M.; Castillero, P.; Cano, M.; Richardson, T. H. Thin Solid Films 2011, 519, 2025.

http://dx.doi.org/10.1016/j.tsf.2010.10.038

29. D’Urso, A.; Cristaldi, D. A.; Fragala, M. E.; Gattuso, G.; Pappalardo, A.; Villari, V.; Micali, N.; Pappalardo, S.; Parisi, M. F.; Purrello, R. Chem. Eur. J. 2010, 16, 10439. http://dx.doi.org/10.1002/chem.201000803

30. Girek, B.; Sliwa, W. J. Incl. Phenom. Macrocycl.Chem. 2015. 81, 35. http://dx.doi.org/10.1007/s10847-014-0454-y

31. Wang, P. S.; Saadioui, M.; Schmidt, C.; Böhmer, V.; Host, V.; Desreux, J. F.; Dozol, J. F. Tetrahedron 2004, 60, 2509. http://dx.doi.org/10.1016/j.tet.2004.01.057 
32. Dam, H. H.; Reinhoudt, D. N.; Verboom, W. Chem. Soc. Rev. 2007, 36, 367. http://dx.doi.org/10.1039/b603847f

33. Grimes, R. N.; Carboranes, Second Ed., Academic: London/Amsterdam/Burlington/San Diego/Oxford, 2011.

34. Grüner, B.; Rais, J.; Selucky, P.; Lucanikova, M. In Hosmane N. S., Ed., Boron Science, New Technologies and Applications, CRC Press: Boca Raton/London/New York, 2011, Chapter 19.

35. Mikulasek, L.; Grüner, B.; Dordea, C.; Rudzevich, V.; Böhmer, V.; Haddaoui J.; Hübscher Bruder V.; Arnaud- Neu J.; Caslavsky, J.; Selucky, P. Eur. J. Org. Chem. 2007, 4772.

36. Grüner, B.; Böhmer, V.; Dordea, C.; Selucky, P.; Bubenikova M. J. Organometallic Chem. 2013, 747, 155.

37. Persson, B. R. R.; Holm, E. J. Environ. Radioact. 2011, 102, 420. http://dx.doi.org/10.1016/j.jenvrad.2011.01.005

38. Bouvier-Capely, C.; Bonthonneau, J. P.; Dadache, E.; Rebiere, F. Talanta 2014, 118, 180. http://dx.doi.org/10.1016/j.talanta.2013.10.010

39. Bouvier-Capely, C.; Manoury, A.; Legrand, A.; Bonthonneau, J. P.; Cuenot, F.; Rebiere, F. J. Radioanal. Nucl. Chem. 2009, 282, 611. http://dx.doi.org/10.1007/s10967-009-0152-1

40. Adhikari, B. B.; Ohto, K.; Schramm, M. P. Chem. Commun. 2014, 50, 1903. http://dx.doi.org/10.1039/c3cc48465c

41. Ikeda, A.; Suzuki, Y.; Yoshimura, M.; Shinkai, S. Tetrahedron 1998, 54, 2497. http://dx.doi.org/10.1016/S0040-4020(98)00012-X

42. Adhikari, B. B.; Gurung, M.; Kawakita, H.; Ohto, K. Analyst 2011, 136, 3758. http://dx.doi.org/10.1039/c1an15199a

43. Toumi, N.; Kajo, F.; Fournier, D.; Vocanson, F.; Lamartine, R.; Dumazet-Bonnamour, I. Mater. Sci.Eng., C. 2008, 28, 645. http://dx.doi.org/10.1016/j.msec.2007.10.009

44. Chiu, C.-T.; Chuang, D.-M. Pharmacol. Ther. 2010, 128, 281. http://dx.doi.org/10.1016/j.pharmthera.2010.07.006

45. Gulino, A.; Lupo, F.; Cristaldi, D. A.; Pappalardo, S.; Capici, C.; Gattuso, G.; Notti, A.; Parisi, M. F. Eur.J. Inorg. Chem. 2014, 442.

http://dx.doi.org/10.1002/ejic.201301213

46. Gulino, A. Anal. Bioanal. Chem. 2013, 405, 1479. http://dx.doi.org/10.1007/s00216-012-6394-8

47. Cristaldi, D. A.; Fragala, I.; Pappalardo, A.; Toscano, R. M.; Ballistreri, F. P.; Tomaselli, G. A.; Gulino, A. J.Mater. Chem. 2012, 22, 675. http://dx.doi.org/10.1039/c1jm13475b

48. Ma, Y. H.; Yuan, R.; Chai, Y. Q.; Liu, X. L. Mater. Sci. Eng. C. 2010, 30, 209. http://dx.doi.org/10.1016/j.msec.2009.10.005 
49. Echabaane, M.; Rouis, A.; Bonnamour, I.; Ben Ouada, H. Spectrochim. Acta, Part A, Mol. Biomol. Spectroscopy 2013, 115, 269.

http://dx.doi.org/10.1016/j.saa.2013.06.053

50. Mlika, R.; Rouis, A.; Bonnamour, I.; Ben Ouada, H. Mater. Sci. Eng. C. 2011, 311466. http://dx.doi.org/10.1016/j.msec.2011.05.017

51. Ward, J. P.; White, J. M.; Young, C. G. Tetrahedron 2013, 69, 8824. http://dx.doi.org/10.1016/j.tet.2013.05.120

52. Kaya, A.; Alpoguz, H. K.; Yilmaz, A. Ind. Eng. Chem. Res. 2013, 52, 5428. http://dx.doi.org/10.1021/ie303257w

53. Ni, X.-L.; Jin, C.-C.; Jiang, X.-K.; Takimoto, M.; Rahman, S.; Zeng, X.; Hughes, D.L.; Redshaw, C.; Yamato, T. Org. Biomol. Chem. 2013, 11, 5435.

http://dx.doi.org/10.1039/c3ob40601f

54. Chen, J.-H.; Hsu, K.-C.; Chang, Y.-M. Ind. Eng. Chem. Res. 2013, 52, 11685. http://dx.doi.org/10.1021/ie401233r

55. Sayin, S.; Ozcan, F.; Yilmaz, M. Mater. Sci. Eng. C 2013, 33, 2433. http://dx.doi.org/10.1016/j.msec.2013.02.004

56. Bhatti, A. A.; Memon, S.; Memon, N.; Bhatti, A. A.; Solangi, I.B. Arabian J. Chem. 2014, 7,125 . http://dx.doi.org/10.1016/j.arabjc.2013.06.033

57. Bayrakci, M.; Ertul, S.; Yilmaz, M. Tetrahedron 2010, 65, 7963. http://dx.doi.org/10.1016/j.tet.2009.07.062

58. Zeng, J.; Guo, Q.; Ou-Yang, Z.; Zhou, H.; Chen, H. Asia. Pac. J. Chem. Eng. 2013, http://dx.doi.org/10.1002/apj.1764

59. Sayin, S.; Eymur, S.; Yilmaz, M. Ind. Eng. Chem. Res. 2014, 53, 2396. http://dx.doi.org/10.1021/ie4020233

60. Sun, Y.; Zhang, F.; Zhang, L.; Luo, L.; Zou, Z.-L.; Cao, X.-L.; Tan, S.-L.; Bi, J.-H.; Tian, D.-M.; Li, H.-B. Chin. Chem. Lett. 2014, 25, 226. http://dx.doi.org/10.1016/j.cclet.2013.10.019

61. Matthias, H. D.; Hannes, S.; Matthias, Z.; Vladimir, A. A. J. Org. Chem. 2013, 78, 4905. http://dx.doi.org/10.1021/jo400502t

62. Erbas-Cakmak, S.; Bozdemir, O. A.; Cakmak, Y.; Akkaya, E. U. Chem. Sci. 2013, 4, 858. http://dx.doi.org/10.1039/c2sc21499g

63. Adarsh, N.; Shanmugasundaram, M.; Avirah, R. R.; Ramaiah, D. Chem. Eur. J. 2012, 18, 12655. http://dx.doi.org/10.1002/chem.201202438

64. Kamakaew, A.; Lim, S. H.; Lee, H. B.; Kiew, L. V.; Chung, L. Y.; Burgess, K. Chem. Soc. Rev. 2013, 42, 77. http://dx.doi.org/10.1039/c2cs35216h

65. Awuah, S. G.; You, Y. RSC Adv. 2012, 2, 11169. http://dx.doi.org/10.1039/c2ra21404k 
66. Atilgan, S.; Ozdemir, T.; Akkaya, E. U. Org. Lett. 2010, 62, 4792. http://dx.doi.org/10.1021/ol1019426

67. Duman, S.; Cakmak, Y.; Kolemen, S.; Akkaya, E. U.; Dede, Y. J. Org. Chem. 2012, 77, 4516.

$\underline{\text { http://dx.doi.org/10.1021/jo300051v }}$

68. Cakmak,Y.; Nalbantoglu T., Durgut, T.; Akkaya, E. U. Tetrahedron Lett. 2014, 55, 538. http://dx.doi.org/10.1016/j.tetlet.2013.11.083

69. Dalbavie, J. O.; Regnouf-De-Vains, J. B.; Lamartine, R.; Lecocq, S.; Perrin, M. Eur. J. Inorg. Chem. 2000, 10, 683.

$\underline{\text { http://dx.doi.org/10.1002/(SICI)1099-0682(200004)2000:4<683::AID-EJIC683>3.0.CO;2- }}$ $\underline{\mathrm{N}}$

70. Haynes, W. M. Ed., CRC Handbook of Chemistry and Physics 2012, 93 ${ }^{\text {rd }}$, Edition, CRC Press: Taylor and Francis : Boca Raton, 2012.

71. Mariano, A. P.; Filho, R. M.; Ezeji, T. C. Renewable Energy 2012, 47, 183. http://dx.doi.org/10.1016/j.renene.2012.04.041

72. Oudshoorn, A; van der Wielen, L. A. M.; Straathof, A. J. J.; Ind. Eng. Chem. Res. 2009, 48, 7325 .

http://dx.doi.org/10.1021/ie900537w

73. Thompson, A. B.; Cope, S. J.; Swift, T. D.; Notestein, J. M. Langmuir 2011, 27, 11990. http://dx.doi.org/10.1021/la202508q

74. Thompson, A. B.; Scholes, R. C.; Notestein, J. M. ACS Applied Materials Interfaces 2014, 6, 289.

http://dx.doi.org/10.1021/am404182m

75. Perret, F.; Morel, J. P.; Morel-Desrosiers, N. Supramol. Chem. 2003, 15, 199. http://dx.doi.org/10.1080/1061027031000078275

76. Nimse, S. B.; Song, K.-S.; Kim, T. Water-soluble Calix[4]arene Derivatives: Binding Stoichiometry and Spectroscopic Evaluation of the Host-Guest Recognition Mechanism. In Stoichiometry and Research- The Importance of Quantitity in Biomedicine, Innocenti, A, Ed., In Tech: Rijeka, Croatia, 2012, 27.

77. Rogers, K. E.; Ortiz-Sanchez, J. M.; Baron, R.; Fajer, M.; de Oliveira, C.A.F.; McCammon, J. A. J. Chem. Theory Comput. 2013, 9, 46.

http://dx.doi.org/10.1021/ct300515n

78. Zhang, X.; Es-haghi, A.; Cai, J. B.; Pawliszyn, J. Journal of Chromatography A 2009, 1216,7664 .

http://dx.doi.org/10.1016/j.chroma.2009.09.021

79. Gallardo-Chacon, J.; Vichi, S.; Lopez-Tamames, E.; Buxaderas, S. J. Agr. Food Chem. 2009, 57, 3279. http://dx.doi.org/10.1021/jf803493s

80. Lin, C. Y.; Liu, C. H.; Chang, H. C.; Tseng, W. L. Electrophoresis 2008, 29, 3024. http://dx.doi.org/10.1002/elps.200700879 
81. Djozan, D.; Ebrahimi, B.; Mahkam, M.; Farajzadeh, M. A. Analytica Chimica Acta 2010, $674,40$.

http://dx.doi.org/10.1016/j.aca.2010.06.006

82. Rocha, C.; Pappas, E. A.; Huang, C. H. J. Environmental Pollution 2008. 152, 239.

http://dx.doi.org/10.1016/j.envpol.2007.04.029

83. Kumar, A.; Gaurav Malik, A. K.; Tewary, D. K.; Singh, B. Analytica Chimica Acta 2008, 610. 1.

http://dx.doi.org/10.1016/j.aca.2008.01.028

84. Wang, X. M.; Liu, J. Y.; Liu, A. F.; Liu Q.; Du, X. Z.; Jiang, G. B. Analytica Chimica Acta 2012, 753, 1 .

http://dx.doi.org/10.1016/j.aca.2012.09.030

85. Tian, M.; Cheng, R.; Ye, J.; Liu, X.; Jia, Q. Food Chem. 2014, 145, 28.

http://dx.doi.org/10.1016/j.foodchem.2013.08.029

86. Gholivand, M. B.; Karimian, N.; Malekzadeh, G. Talanta 2012, 89, 513.

http://dx.doi.org/10.1016/j.talanta.2012.01.001

87. Woodruff, D. N.; Winpenny, R. E. P.; Layfield, R. A. Chem. Rev. 2013, 113, 5110. http://dx.doi.org/10.1021/cr400018q

88. Zhang, P.; Guo, Y.-N.; Tang, J.-K. Coord. Chem. Rev. 2013, 257, 1728.

http://dx.doi.org/10.1016/j.ccr.2013.01.012

89. Wang, Y.-L.; Ma, Y.; Yang. X.; Tang, J.-K.; Cheng, P.; Wang, Q.-L.; Li, L.-C.; Liao, D.-Z. Inorg. Chem. 2013, 52, 7380.

http://dx.doi.org/10.1021/ic400006n

90. Ren, M.; Pinkowicz, D.; Yoon, M.; Kim, K.; Zheng, L.-M.; Breedlove, B. K.; Yamashita, M. Inorg. Chem. 2013, 52, 8342.

http://dx.doi.org/10.1021/ic400430q

91. Chilton, N. F.; Langley, S. K.; Moubaraki, B.; Soncini, A.; Batten, S. R.; Murray, K. S. Chem. Sci. 2013, 4, 1719.

http://dx.doi.org/10.1039/c3sc22300k

92. Gao, F.; Cui, L.; Song, Y.; Li, Y.-Z.; Zuo, J.-L. Inorg. Chem. 2014, 53, 562.

http://dx.doi.org/10.1021/ic4026624

93. Kahlfuss, C.; Metay, E.; Duclos, M.-C.; Lemaire, M.; Oltean, M.; Milet, A.; Saint-Aman, E.C. Compt. Rend. Chim. 2014, 17, 505.

http://dx.doi.org/10.1016/j.crci.2014.01.006

94. Matvieiev, Y.; Solovyov, A.; Shishkina, S.; Shishkin, O.; Katz, A.; Boiko, V.; Kalchenko, V. Supramolecular Chem. 2014, 26, 825. http://dx.doi.org/10.1080/10610278.2014.882511

95. Pang, T.-T.; Liu, H.-L.; Du, L.-M.; Chang, Y.-X.; Fu, Y.-L. J. Fluoresc. 2014, 24, 143. http://dx.doi.org/10.1007/s10895-013-1280-0 
96. Espinas, J.; Pelletier, J.; Szeto, K. C.; Merle, N.; Le Roux, E.; Lucas, C.; De Mallmann, A.; Basset, J.-M.; Taoufik, M.; Thivolle-Cazat, J. Microporous Mesoporous Mater. 2014, 188, 77. http://dx.doi.org/10.1016/j.micromeso.2013.12.031

97. Rebarz, M.; Marcelis, L.; Menand, M.; Cornut, D.; Moucheron, C.; Jabin, I.; Kirsch-De, M. Inorg. Chem. 2014, 53, 2635.

http://dx.doi.org/10.1021/ic403024z

98. Liu, W.; Liu, M.; Du, S.; Li, Y.; Liao, W. J. Mol. Structure 2014, 1060, 58. http://dx.doi.org/10.1016/j.molstruc.2013.12.044

99. Zhou, Y.; Tan, L.-L.; Li, Q.-L.; Qiu, X.-L.; Qi, A.-D.; Tao, Y.; Yang, Y.-W. Chem. - $A$ European J. 2014, 20, 2998.

http://dx.doi.org/10.1002/chem.201304864

100. Rebilly, J.-N.; Reinaud, O. Supramolecular Chem. 2014, 26, 454. http://dx.doi.org/10.1080/10610278.2013.877137

101. Sengupta, A.; Godbole, S. V.; Mohapatra, P. K.; Iqbal, M.; Huskens, J.; Verboom, W. J. Lumin. 2014, 148, 174.

http://dx.doi.org/10.1016/j.jlumin.2013.12.009

102. Zhou, X.-M.; Chen, W.; Song, Y.-F. Eur.J. Inorg. Chem. 2014, 2014, 812.

103. Valluru, G.; Georghiou, P. E.; Sleem, H.F.; Perret, F.; Montasser, I.; Grandvoinnet, A.; Brolles, L.; Coleman, A. W. Supramolecular Chem. 2014, 26, 561. http://dx.doi.org/10.1080/10610278.2013.872247

104. Chen, Z.; Liu, J.; Evans, A. J.; Alberch, L.; Wei, A. Chem. Materials 2014, 26, 941. http://dx.doi.org/10.1021/cm402484x

105. Arnott, G. E.; Moquist, P.; Daniliuc, C. G.; Kehr, G.; Erker, G. Eur. J. Inorg. Chem. 2014, 2014, 1394.

106. Barata, P. D.; Prata, J. V. ChemPlusChem 2014, 79, 83. http://dx.doi.org/10.1002/cplu.201300280

107. Hassinen, J.; Pulkkinen, P.; Kalenius, E.; Pradeep, T.; Tenhu, H.; Hakkinen, H.; Ras, R. H. A. J. Phys. Chem. Lett. 2014, 5, 585. http://dx.doi.org/10.1021/jz500052h

108. Sliwka-Kaszynska, M.; Slebioda, M. J. Separation Sci. 2014, 37, 543. http://dx.doi.org/10.1002/jssc.201301038

109. Bi, X.; Sun, J.; Liu, W.-L.; Yan, C.-G. J. Incl. Phenom. Macrocycl. Chem. 2014, 80, 235. http://dx.doi.org/10.1007/s10847-014-0382-X

110. Bonaccorso, C.; Brancatelli, G,; Ballistreri,F.P.; Geremia, S.; Pappalardo, A.; Tomaselli, G.; Toscano, R. M.; Sciotto, D. Dalton Transactions 2014, 43, 2183. http://dx.doi.org/10.1039/c3dt52550c 


\section{Authors' Biographies}

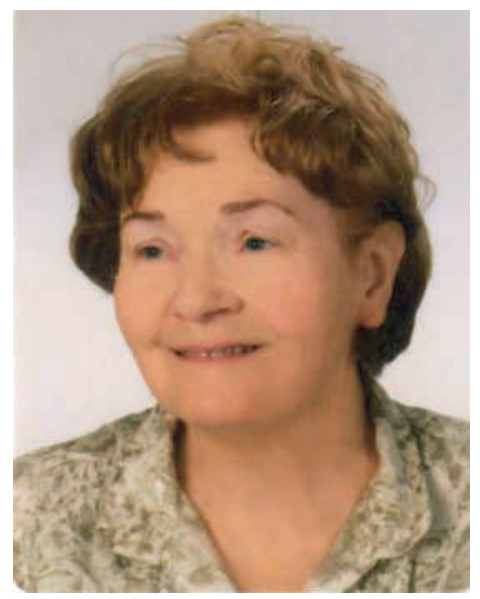

Wanda Sliwa graduated from Wrocław University of Technology, Poland where she became an associate professor. After a year research at Université Paul Sabatier a Toulouse, France, she moved to Jan Dlugosz University of Czestochowa, Poland, where she has been Professor of Chemistry since 1990, as well as being a vice-rector, head of the Organic Chemistry Department and director of the Institute of Chemistry. She is author or coauthor of four books and 16 monographs, around 350 papers and ten patents, and has received several awards for scientific and pedagogical achievements. Her research concerns azaaromatic compounds and supramolecular chemistry.

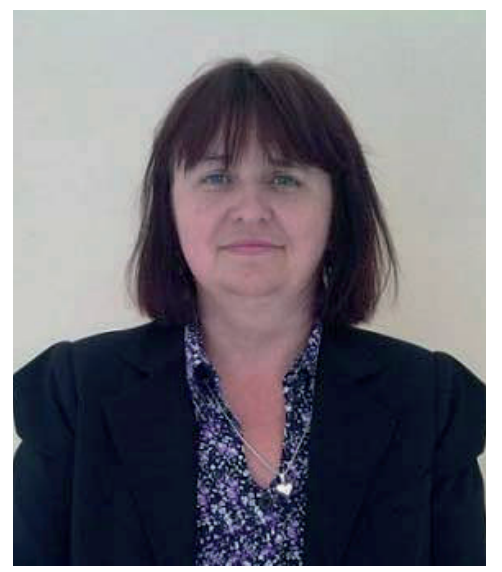

Malgorzata Deska graduated from Pedagogical University of Częstochowa, Poland, she received there M.Sc. degree in 1990. Since this time she works at Jan Długosz University (formerly Pedagogical University) of Częstochowa in Organic Chemistry Department and in Biochemistry Department. In 2004 she obtained her PhD at Technical University of Cracow, the doctor thesis concerned physicochemical properties of diazaphenanthrenes. She has published 18 papers in refereed journals, 7 communications to scientific meetings and is a coauthor of a book. The research interests of Dr. Malgorzata Deska are connected with chemistry of heterocyclic compounds, cyclodextrins and calixarenes. 


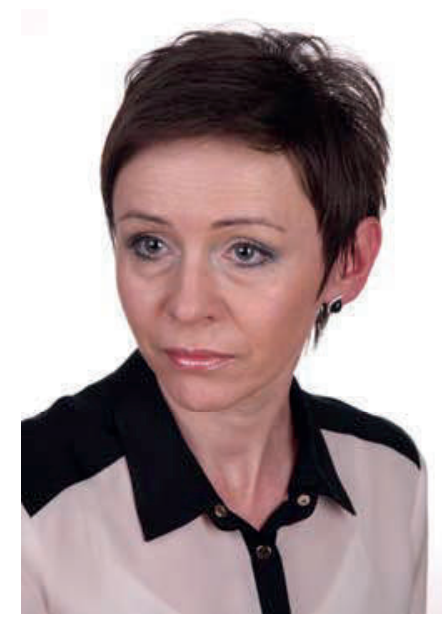

Barbara Dondela graduated from Pedagogical University of Częstochowa, Poland, she received there M.Sc. degree in 1995. Since this time she works at Jan Długosz University (formerly Pedagogical University) of Częstochowa in Organic Chemistry Department. In 2002 she obtained the Sc.D. at Jagiellonian University of Krakow, her doctoral thesis concerned physicochemical properties of diazaphenanthrenes. The research interests of Dr Barbara Dondela are connected with cage macrocycles and chemistry of ionic liquids. 